\title{
Rethinking poverty, power and privilege: A feminist post-structuralist research exploration
}

\begin{abstract}
Author:
Thérèse Hulme ${ }^{1}$

Affiliation:

${ }^{1}$ Department of Practical

Theology, University of South

Africa, Pretoria, South Africa

Note:

This article is based on

the author's DTh thesis in

Practical Theology at Unisa,

entitled 'Pastoral care and

the challenge of poverty:

When opening hearts and

minds creates possibilities

in a marginalised school

community.' The promoter

was Dr D.J. Kotzé.
\end{abstract}

This article is published in the section Practical Theology of the Society for Practical Theology in South Africa.

Correspondence to:

Thérèse Hulme

Email:

hulme@medinet.co.za

Postal address:

26 Plettenberg Street,

Welgemoed 7530,

South Africa

Dates:

Received: 11 May 2012

Accepted: 24 Aug. 2012

Published: 29 Nov. 2012

How to cite this article:

Hulme, T., 2012, 'Rethinking poverty, power and privilege:

A feminist post-structuralist research exploration',

HTS Teologiese Studies/

Theological Studies 68(2),

Art. \#1263, 7 pages. http://

dx.doi.org/10.4102/hts.

v68i2. 1263
C 2012. The Authors. Licensee: AOSIS OpenJournals. This work is licensed under the Creative Commons Attribution License.
In this article, I described how the use of feminist methodology and post-structuralist analyses of the experiences of women in a poor 'Coloured' community in my research led to new understandings of the experiences of poverty and privilege. I discovered the relevance of Foucault's historical analysis of the operation of 'pastoral power' through the narratives of women from the Scottsville community. Historical and current accounts of so-called 'Coloured' women's subjugation and categorisation are reminders of how it came about that 'being Coloured' became associated in South Africa with shame and with 'knowing one's place'. Feminist post-structuralist analyses made visible the conditions that created practices of injustice in poor women's lives whilst, at the same time, creating conditions of privilege for me. Justice-making in Scottsville therefore started with a radical rethinking of the terms by which people's marginalisation took place and, consequently also of the terms of 'just' crosscultural engagements.

\section{Introduction}

In 2005 I began my doctoral research in Practical Theology by working as a narrative pastoral

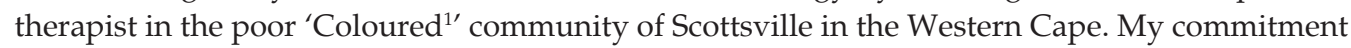
to engaging with poor and marginalised people found its theological expression and was supported in my research, in the first instance, by liberation theology, and more specifically by the methodologies within a feminist theological epistemology geared towards liberation and justice.

What emerged for me during the research was the fact that the use of power that led to 'Coloured' people's marginalisation does not only refer to a historical or political reality. Strategies of power that have as their object the subjugation, categorisation and control of people still govern the relations between many adults and between adults and young people in 'Coloured' communities. Therefore, any meaningful engagement with people in these communities should be based on an awareness of these strategies of power and their objectives. If we fail to take cognisance of such strategies, as researchers, counsellors and community workers, we are in danger of replicating the very forms of control by which some members of society have been subjugated and silenced.

\section{The role of social analysis in theology}

According to Cochrane, De Gruchy and Petersen (1991:30-31), social analysis therefore becomes imperative if we as theological researchers and practitioners want to practice theology that can claim to be socially relevant. De Gruchy (1994:11) refers to the role of the social sciences in providing 'necessary tools and resources for analysing the context within which the church is called to proclaim and live the gospel.' The theoretical positions of both contextual and liberation theologies regard social analysis as indispensable. However, Pattison (1994) argues that one:

of the surprising features of liberation theology is that, while social analysis is much talked of, and the voice of the social sciences is supposed to be a prominent 'first voice' in theological method, there is very little concrete exemplification of this approach in practice. (p. 63)

According to Poling (2002:221), in pastoral theology and counselling, we need cultural and economic analyses in order to generate understanding about differences, whilst recognising that these differences are often unfairly organised according to race, gender, sexuality and culture. Furthermore, he advocates cultivating an understanding of cultural and economic dominance, which he describes as 'the ability of some groups to make their values the norm by which all other cultures are allowed to exist.' What a feminist hermeneutic has added to this research something neither contextual theology nor liberation theology could offer - is its link with post-

1.In this article reference is made to a specific South African community with a specific social location and history which is 'not White' and 'not Black'. Because this is a description that was not chosen by a group of people, but forced upon them, I place the word in inverted commas to reflect the historical subjugation that this term speaks of. The word is specifically chosen rather than the more politically correct 'mixed race', because classification as 'Coloured' is a daily reality for the community that formed the focus of the study. The correct 'mixed race', because classification as 'Coloured' is a daily reality for the community that formed the focus of the study. The
word 'Coloured' was preferred to the term 'Brown' by the women of Scottsville, who are referenced in this article. This choice was also word 'Coloured' was preferred to the term 'Brown' by the women of
made because of the use of the term in the relevant literature cited. 
structuralist analysis, which enables the understanding that Poling advocates. Elaine Graham (1993:211) points out that 'attention to the politics of pastoral care, therefore begins with the realization that pastoral relationships cannot be isolated from their broader social and cultural setting.'

\section{What is meant by 'post-structuralist analysis'?}

The development of what is termed 'post-structuralism' is linked to what philosophers regarded as the limitations that a structuralist's world view held for human relationships. Post-structuralism emerged as a school of thought in France in the 1960s and 'began to challenge structuralist claims to objectivity and comprehensiveness and ... emphasized instead the plurality and deferral of meaning' (Knowles \& Elliott 1997:241). According to Graham (1996:100), 'structuralism understands all actions, rituals and institutions as expressions of pre-existent binary oppositions which are embedded in all human behavior.' Relationships that are governed by the rules of binary oppositions perpetuated 'the old medieval and pre-Christian division of the world into good and bad, black and white, body and mind' (Isherwood \& McEwan 1994:63).

Research that is conducted within a post-structuralist paradigm is therefore geared towards questioning the kind of power that has created specific relational discourses and has upheld such discourses as 'objective truths' according to which society organised itself into binary oppositions. As Weedon (1987:19) points out, post-structuralism lends itself to multiform interpretations and is 'applied to a range of theoretical positions.' In both pastoral care and theology, terms such as 'pastoral' and 'transformation' are often used in ways that suggest universal meaning. However, within a post-structuralist discourse, such terminologies need to be described contextually in order for them to have any practical relevance.

Post-structuralist analysis enabled me to take a critical look at the ways in which power relations are structured and maintained through the operation of discourses that legitimise the control that some people exert over others. It also sensitised me to those voices in communities that are silent, and to how they could have been silenced in this way. It made me aware of the blind spots in my own seeing, listening and understanding because of my own privilege. I realised that, as a White person in South Africa, my ability to understand the complexities associated with 'Coloured' poverty was limited. Feminist post-structuralist analysis therefore provided me with the tools with which to question the rules by which social relations, including my own, have been and continue to be structured. Brueggemann (1976) links such a questioning stance with the purpose of shalom:

If we are to be seriously engaged with our faith, then we must be more sensitized to a central shalom question: How are things ordered? How did they get that way? Who wants to keep it that way? For what vested reason do they want to keep it that way? Shalom leads us to raise issues of sociology of value and sociology of power. (p. 74)
Feminist post-structuralism thus offers a theory that addresses:

the questions of how social relations of gender, class and race might be transformed. It implies a concern with history, absent from many poststructuralist perspectives but central to the work of Michel Foucault. (Weedon 1987:20)

The analysis of the writings of the French philosopher and post-structuralist, Michel Foucault, therefore provided my research with its 'first voice' for a theological method. To be able to determine what just research in a context of poverty is, I therefore started questioning what type of power creates practices of injustice, what its terms of reference are and what discourses are associated with it.

\section{The emergence of 'pastoral power'}

In several lectures that he gave between 1977 and 1978 at the Collège de France, Foucault (2007) analysed the emergence of a particular kind of pastoral power in the Christian church and the laws that governed this emergence. Foucault (2007:152) argues that, in Hebrew society, no individual took up the position of pastor in relation to others. With the exception of David:

the Hebrew King is never designated positively, directly, or immediately as a shepherd. There is no shepherd outside of God. On the other hand, in the Christian Church we see instead the, as it were, autonomization of the shepherd theme in relation to other themes, as not merely one of the dimensions or aspects of God's relationship to men. It will become the fundamental, essential relations, not just one alongside others but a relationship that envelops all the others and, second, a relationship that will, of course, be institutionalized in a pastorate with its laws, rules, techniques, and procedures. (Foucault 2007:152)

Foucault claims that the organisation of the Church 'presents itself as a pastoral organization. The powers held by the Church are given, I mean both organized and justified, as the shepherd's power in relation to the flock' (Foucault 2007:153). Foucault gives several examples of how this power manifests itself in practices such as the power of giving communion, of giving penance, of baptism, and of jurisdiction. Foucault (2007:153) therefore contends that 'religious power, therefore, is pastoral power.'

According to feminist theologian Sharon Welch (1990), although:

rituals and doctrines that affirm the absolute power of God also claim that such power is had only by God, they also reinforce a human desire for absolute power. (p. 111)

Or as Rieger (1998:21) puts it: 'From the perspective of the modern self, authority is related to the ability to control.' Thus the valorisation of power as control has been institutionalised in theological discourse and in its pastoral practices. For Foucault, a 'discourse' is a body of thought and writing that is united by having a common object of study, a common methodology, and/or a set of common terms and ideas; the notion of discourse thus allows Foucault to talk about a wide variety of texts, from different countries, different historical periods, different disciplines and different genres. 
Foucault gives a detailed and meticulously researched description of the features of pastoral practice that emerged from the centralisation of the shepherd-flock relationship. For the purposes of this research, I focus on the practices of subordination, classification and the objective of 'docile bodies' that Foucault describes. I believe that such a genealogy of pastoral power is essential in order to understand the possibilities of practice within the Christian community and how they influence what is possible in individual relationships as well:

The Christian pastorate has, I think, organized something completely different that seems to me to be foreign to Greek practice, and this is what we would call the insistence on 'pure obedience'. (Foucault 2007:174)

This obedience, Foucault (2007) proposes, finds expression in the mechanism of 'complete subordination' which means that:

it is a relationship of submission, but not submission to a law or a principle of order, and not even to a reasonable injunction ... It is a relationship of the submission of one individual to another. The relationship of submission of one individual to another individual, correlating an individual who directs and an individual who is directed, is not only a condition of Christian obedience, it is its very principle. (p. 175)

Foucault recounts narratives of institutionalised subordination in monasteries in the relationship between abbot or superior, master and novice (Foucault 2007:175-176), where commands had to be obeyed no matter how absurd or unreasonable they seemed, but simply because they 'had been given'.

Foucault (2007) makes the point that this relationship is not finalised when obedience results in some kind of knowledge or even skill which will enable a person to become master of him- or herself, but that it results in aiming for a state of:

humility, which consists in feeling oneself the least of men, in taking orders from anyone, thus continually renewing the relationship of obedience, and above all in renouncing one's own will. (p. 177)

The renouncing of one's own will and thinking nothing of oneself can therefore become proof of the level of obedience attained. It becomes both the measure of faith and an indication of whether faith is attained, a measure against which individuals may be judged.

Elaine Graham (1993:217) expresses a similar view, pointing out that the 'use of images like that of the shepherd to delineate the scope and nature of pastoral care perpetuates models of care which emphasize individualism, professionalism, and directivity.' Schüssler Fiorenza (1993:224) also refers to the 'patriarchalization and hierarchalization of the church', a process that resulted in a shift in terms of the regard in which the church holds certain values, 'mutuality and solidarity amongst Christians no longer connotes a "new reality", but becomes reduced to mere moral appeal' (Schüssler Fiorenza 1993:223-224). Schüssler Fiorenza (1993:224) argues that 'submission and obedience, but not equality and justice, are institutionalized by this patriarchal ethos.'
Foucault (2007) then makes the connection between the institutionalisation of the Christian pastorate and Christian morality:

both in the history of ideas and for the practice itself, as also for all the problems of what is called the 'flesh' in Christ. As you can see, it involves the difference in successive meanings given to the same word apatheia, the apatheia to which, precisely, obedience strives. (p. 178)

If this is the object of the Christian pastorate, then Foucault (2007:178) asks a crucial question: 'What does the absence of pathé, of passions, mean for Christianity?' The effect of a culture of submission is that the individual's obedience and apathy becomes the norm. My research therefore specifically examined the power dynamic of pastoral relations in a context of poverty as part of its scope. Thus the 'sheep' within the pastoral model proposed by Foucault are specific sheep: they are economically powerless and socially marginalised sheep, who submit to the authority of another. The more I listened to the narratives of submission and control of the Scottsville women, the more I realised that a post-structuralist analysis obliged me to inquire about the history of the 'meticulous, often minute techniques' (Foucault 1995:139) of power with the aim of subjecting the bodies of 'Coloured' people.

\section{A historical analysis of the operation of 'pastoral power' in the 'Coloured' community Categorisation and classification}

Pastoral relations have for many years depended on a categorising principle at work, where for instance, the male is categorised as the head, the norm, and the female as the support, the auxiliary to the norm. Hence the idea of centre and margin: the 'inside', the norm, the primary principle against which everything else is judged, and the marginal, the outside, that which is being judged against the norm.

This categorising and classifying principle has gained enormous significance in the way in which it has affected race and social relations in South Africa. Race classification has also affected the way in which 'Coloured' people regard themselves. Zimitri Erasmus (2001:13) explains, 'growing up coloured meant knowing that I was not only not white, but less than white; not only not black, but better than black.' She states that 'colouredness as an identity ... has always been understood as a residual, in-between, or "lesser" identity - characterised as "lacking", supplementary, excessive, inferior or simply non-existent' (Erasmus 2001:15-16).

Reddy (2001) therefore contends that in:

a rigidly, hierarchically structured racial classificatory system, there will and must be a category for the unclassifiable - the Other - which resists the discourse but also functions to give the classificatory system its very meaning. Coloured has been the home for this function in South Africa. (p. 68)

Historian Hermann Giliomee (2007:18-19) describes the effects such a prevailing rationale had on the relations 
between masters, slaves and the pastorate between 1665 and 1795 in the district of Stellenbosch. The Synod of Dordrecht (of 1618-1619) decreed that whoever was baptised should have the same right to freedom as other Christians. Hence, very few masters had their slaves baptised, because baptised slaves, by law, could not be sold. But Giliomee (2007:19) offers another reason why masters did not baptise their slaves: they feared that a baptised slave would regard himself the equal of his master and that it would then be very difficult to control him. The slave would not, so it was said, 'know his place'. This historical analysis reveals how the function of pastoral power may outlive the ecclesiastical institution with which it was originally associated, as Foucault describes. What this piece of historical analysis also reveals is that the experience of being a slave cannot be separated from the experience of being a master. To this day, the discourse of 'knowing your place' functions outside the church to subordinate the descendants of slaves, namely the 'Coloured' community.

A post-structuralist epistemology then works not toward a quest for 'origins' or 'truth' of events, values or knowledge, but rather creates an awareness of how knowledge is constituted through discourses:

Consequently, those who resist or rebel against a form of power cannot merely be content to denounce violence or criticize an institution. What has to be questioned is the form of rationality at stake. (Foucault [1979] 2003:201)

The rationality of the discourse of 'knowing one's place' has gained 'truth' status in the 'Coloured' community and over centuries has constituted the selves of real poor people. One of the operations of pastoral power as control, as making others 'know their place', becomes clear through Ms Cupido's narrative below. Her narrative tells the story of a subjugating power whose intention was the creation of 'docile bodies'. According to Foucault (1979:41), 'docile bodies' are subjugated bodies that will submit and obey orders. Foucault uses the term 'bio-power', to locate the experience of power in the bodies of people. The narrative of Ms Cupido tells of the many ways in which 'the body is invested with relations of power and domination' (Foucault 1995:25-26), and of the effects that the operation of bio-power had on her and her community. In South Africa, during the apartheid years, docile bodies were forcibly removed from their homes so that their land could be used for the purposes of those in power.

Benhabib (1992:222) argues that for 'Foucault there is no history of the victims but only a history of the construction of victimization.' Feminism, however, is interested in the recovery, uncovery and discovery of the experiences of those whose voices have been silent due to victimisation. Whilst the narratives below illuminate Foucault's themes of the object of 'pastoral power': subjugation, 'apatheia' and the creation of 'docile bodies', it also gives account of real 'Coloured' women's experiences of marginalisation, lack of opportunity and poverty.

\section{Feminist methodology Social analysis at a local level}

In his provocative article 'Questioning contextual theology', James Cochrane (2001:67-86) points out that the challenge for contextual theology lies therein that it needs to provide social analysis at a local level, and according to the categories provided by the people in those contexts. Cochrane (2001) argues that:

our solidarity can only be with those who are hurt, subjugated or otherwise marginalized by the institutions and procedures by which we organize our life together in society. It is from that point of view, with such people as our first interlocutors and their experiences as our first point of reference for analysis, that critical engagement with government and other agencies in our society becomes valuable, and vital. (p. 85)

In line with feminist theology, the experiences of poor people themselves, especially women (Isherwood \& McEwan 1994:80), are used as my first point of reference for social and theological analysis. By regarding poor people as my first interlocutors, my feminist methodology in this article thus practises what it preaches, namely to return social and theological power to those who have been disempowered by social and theological structures. Such a methodology makes the effects of power clear in human, relational terms. Both the post-structuralist and feminist epistemologies therefore deal with pastoral power, but from different and complementary perspectives.

\section{Challenging marginalising discourses}

\section{The story of Anna Tarentaal}

One of the effects that the marginalisation of women has had in poor communities is that when it comes to making a contribution, many of these women have been led to believe that they have little if anything to offer that is of value outside of their immediate context. The disabling discourses of submission and apatheia have succeeded in making these women's contributions seem inconsequential and invisible, even to themselves. Mujerista feminist theologian, Ada María Isasi-Díaz (1999) writes:

What has erupted and threatens to dislodge the subjugating aspects of the rationality of modernity is not the theories of the academy, the debates about post modernity, but the insistence of subjugated people on being subjects of their own histories, on being central characters in their own narratives. (p. 231)

The story of Anna is a case in point. Anna Tarentaal came to the first of several lay counselling workshops that I offered in the community in 2006. During the first session I asked the women to introduce themselves. Anna spoke about her love of children and shared with us the fact that, when she was young, she looked after her brother, who lived with cerebral palsy. Anna also spoke about her faith in God and the fact that she was an active member of her church community. I then introduced the ways in which I would be working, telling the women that they could make notes if they wished to do so. During the tea break, Anna left the room. I could see that 
she was upset. I caught up with her on her way to the gate. When I asked her what the tears were about, Anna broke down. Through her tears she told me that she was illiterate and that because of it she thought that the course was not for her. Thinking back to the caring for her brother that her introduction to the group spoke of and knowing that Anna's faith in Christ was central to her life, I asked her: 'When Jesus chose his disciples, how important do you think He regarded reading and writing as an ability?' Anna suddenly stopped crying. Then, wiping the tears from her cheeks, she said: 'Not important ... OK, then I will stay.'

Because of the existence of the social category of literacy, which is regarded as the norm, as opposed to the category of illiteracy, as that which is outside of the norm, Anna experienced shame and lack in terms of what was expected of her as a lay counsellor. What my question did was to deconstruct the importance of the category of writing in terms of Jesus' own life and the decisions he made. Because I chose not to preach, but to ask a question, Anna was invited to deconstruct the meaning about the literacy/illiteracy binary herself in terms of her understanding of the meaning of Jesus' life. White (2000) points out that the unpacking of identity categories (such as 'I am illiterate') can:

contribute very significantly to an appreciation of complexity of these categories, and to the rich description of knowledges and skills of living that are associated with them ... it is through this deconstruction that complexity is apprehended. And it is in the apprehension of this complexity that more options for action in the world become available to people. (p. 167)

The unpacking of illiteracy in the context of Anna's faith in Jesus did indeed bring with it an immediate and rich description of knowledge: being literate is not a valued identity category for Jesus in doing God's work. The knowledge that emerged for Anna from this question made 'more options for action in the world available' to her, one of which was staying in the group. It also lifted the burden of shame around illiteracy for her.

At our next session, Anna told the group of the transformative effect that the previous session had on her:

'Something happened inside of me. I realised I am somebody although I had been thinking I am nothing and I too can do something with my life if I want to. I can also help others. I felt so good. I could almost not sleep. It moved me deeply.'

\section{Elizabeth Cupido narrates history}

During the time of the forced removals in South Africa, one family that had to move three times was the family of Ms Elizabeth Cupido of Douglas in the Northern Cape. Ms Cupido, who now resides in Scottsville, and whom I got to know through the lay counselling sessions that I offered in the community, agreed to talk with me for the purposes of my research:

E: 'Then it happened. We also had to move. It was announced that they were building a golf course where we lived. Our stone kraal had to be flattened. My father had to sell his livestock, which caused him to suffer terrible losses. And a golf course was built where we lived. My mother ran a small farming business from home. In the afternoons when we got home from school, we went to the chicken coops to collect eggs, because our clients had to receive eggs.'

T: 'So you were part of the business?'

E: 'We were part of the business. In the mornings my brothers did the milking. And everyone who went to school had to deliver milk ... we each had certain people.'

T: 'So it's not only about moving, it's about a whole way of life ...?'

E: [Pants] 'One actually also becomes impoverished. Look, from that income my mom could ... at that time Douglas did not have a high school. And two of my sisters were already attending high school in Kimberley. So she could pay their boarding fees. She made our own dresses, so she could buy her fabric ...'

T: '... and then it was taken away?'

E: [Gasps for breath] 'You know, the diggers ... we grew up as brothers and sisters and it was torn apart ... Then the closeness was no longer there. You had to go to where they had built the small council house. And today one is still bitter ... [long silence] when you stand on the ridge and you look ... like recently when I was there on holiday ... and in the mornings, the sprinklers are [spraying] on the golf course. If you consider that this was our home. Then it was for them, for their pleasure.It causes bitterness. People had to start all over again furnishing their small house, because furniture breaks during a move. And our lovely school, our lovely school ... when it was apricot season, we could go outside and then you pick apricots in the schoolyard ... our pomegranates ... our lovely church, our parsonage ...'

T: 'What happened to it?'

E: 'Demolished. As you know it was in the town.'

T: 'Were the church and the school demolished?'

E: '... the church and the school and the parsonage were demolished. All that is left ... I can take you there today ... is the two pillars that supported the bell. [Silence]

Ms Cupido told me that when she was ten or eleven, they had to move house because of the Group Areas Act. Until then, her mother's small-scale farming business enabled her mother to send her two older sisters to Kimberley, as she could afford the hostel fees. To get a high school education, in those days, 'Coloured' young people from Douglas had to go to Kimberley, 107 kilometres away. There was only a White high school in Douglas at the time. As a result of this particular forced removal, the family had to give up its farming business. This, in turn, meant that when it was time for Elizabeth to go to Kimberley, there was no money to pay the hostel fees. She had to leave school:

E: 'My mother will always recount how I cried because I also wanted to go, I also wanted to go [to high school]. I always wanted to be a nurse [sobs]. She could not send me to high school, because there was no money. The unjust system took my education away from me ...'

Ms Cupido's narrative illustrates how institutionalised pastoral power had set in motion a series of actions through which 'Coloured' people's lives and bodies were subjected 
and controlled. The bodies of 'Coloured' people had to, literally, become 'docile' in order that their homes, school and church could be demolished and their land confiscated. Ms Cupido describes how the policy of forced removals had impoverished her family. Moreover, the family's move not only changed a particularly pastoral way of life but also had a dramatic impact on the educational opportunities available to Ms Cupido.

\section{Rethinking privilege}

In a feminist post-structuralist epistemology, a researcher is not outside of that which he or she researches. A poststructuralist researcher therefore does not claim neutrality, but admits that the ways in which he or she has been constituted influence how he or she listens and what he or she hears (Davies \& Harré 1991:58). As a speaking, writing and (in this case) listening post-structuralist researcher, I am therefore not only historically situated in relation to Ms Cupido's story, but also bring my own race and education to my listening and my understanding of her story.

Whilst listening to Ms Cupido in her small sitting room, something strange and new happened to me. Ms Cupido's narrative of personal grief, community fragmentation and unfulfilled dreams against the backdrop of the destruction of a 'pastoral' existence, went beyond epistemology. What Foucault had introduced me to, Ms Cupido brought home to me in bodily ways I had never experienced whilst reading Foucault, or feminist theorists, for that matter. What was different about this experience was that I was implicated in her experience. I was no 'neutral' reader reading about power relations in a French asylum. This was South Africa. We were speaking in the same mother tongue. And yet, there was bitter irony in the fact that she could not go to high school and I was interviewing her about this experience for my doctoral thesis. Whilst I grew up with limitless opportunity because of being a White person, Ms Cupido, who longed to be a nurse, had to serve customers in a butchery. The painful realisation of our connectedness and of the connectedness between poverty and privilege in South Africa, has become the basis of my sense of obligation to do voluntary community work in the Scottsville community ever since.

\section{Theological implications}

In the epilogue to their authoritative publication on qualitative research, Lincoln and Denzin (2005:1117) see four main political features as part of the future of qualitative research: 'the reconnection of social science to social purpose; the rise of indigenous social science(s) crafted for the local needs of indigenous peoples; the decolonization of the academy' and the use of new approaches by social scientists. My research on which this article is based, has demonstrated how the social science of philosophy in the form of Foucault's work was used with the purpose of explaining and describing the link between pastoral power relations and the experiences of poverty and marginalisation of 'Coloured' women. But most importantly, the research's decolonisation of the academy lies in the description of those methodologies that centralised the experiences and knowledges of ordinary and marginalised people and my embodied participation with them. In order to be just, I discovered that practical theology depends on this participation.

\section{Feminist theologian Carter Heyward (1999) suggests that:}

the only way we can live fully in God in this world at this time is to embody God's own yearning for that which is not yet - the completion, or fulfilment, of creation. (p. 22)

Therefore, research that keeps the uncertain and unfinished nature of our social realities and God's reality in mind, invites us into a process of critique whereby we are called to coformulate what 'not yet' means in practical and social terms. In a context of poverty and marginalisation I discovered that the 'not yet' of participation demanded of me: a vulnerability to the suffering of others, an attitude of humility instead of wanting to control, and to care with my body for the body of another. In this regard, Joan Tronto (1995:141) argues: 'care provides the basis for the most important form of contemporary radical political thinking.'

Taking 'not yet' seriously means that participation in poor communities is motivated by the ongoing longing to realise that which has not been thought, imagined or realised before:

Rather than presenting our yearning for fulfilment as sacred, a dimension of God's own presence with us, the church has tried to complete the redemption story by suggesting that, in Jesus' death, God's desire for right relation with creation was finally completed or 'satisfied.' I believe that such a theology shortcircuits the Spirit's movement in history, and, moreover, I believe that through Jesus' living and dying and through our lives as well - in our yearning for a righteousness that is unfulfilled, a justice-love that has not been satisfied - God's longing is God's holiness, and so to is our own. (Heyward 1999:25, [author's own emphasis])

I am reminded of Jesus' words about the coming of the Kingdom here (Lk 17:20-21): the Kingdom has not yet come, but its possibility, Jesus implies, lies with us and our practice. It is a vision that compels us to work to transform a pastoral culture by going beyond the limits of how such a culture or tradition defines itself.

Community practice and/or research flowing from a yearning for justice is therefore by its very nature questioning how relationships of power are set up, the discourses through which it is maintained and how its operation affects the lives of others. At the same time, my feminist understanding of faith-as-praxis offers the possibility that the power of control can, and should, be transfigured and that cross-cultural relationships in South Africa can be made new.

\section{Acknowledgements Competing interests}

The author declares that she has no financial or personal relationship(s) which may have inappropriately influenced her in writing this article. 


\section{References}

Benhabib, S., 1992, Situating the self, Routledge, New York.

Brueggemann, W., 1976, Living toward a vision: Biblical reflections on shalom, United Church Press, Philadelphia, PA.

Cochrane, J.R., 2001, 'Questioning contextual theology', in M.T. Speckman \& L.T. Kaufmann (eds.), Towards an agenda for contextual theology: Essays in honour of Albert Nolan, pp. 67-86, Cluster, Pietermaritzburg.

Cochrane, J., De Gruchy, J. \& Petersen, R. (eds.), 1991, In word and deed: Towards a practical theology of social transformation, Cluster, Pietermaritzburg.

Davies, B. \& Harré, R., 1991, 'Positioning: The discursive production of selves', Journal for the Theory of Social Behaviour 20(1), 43-63. http://dx.doi. org/10.1111/j.1468-5914.1990.tb00174.x

De Gruchy, J.W., 1994, 'The nature, necessity and task of theology', in J.W. de Gruchy \& C. Villa-Vicencio (eds.), Doing theology in context: South African perspectives, pp. 2-14, Orbis, Maryknoll, NY.

Erasmus, Z., 2001, 'Re-imagining coloured identities in post-Apartheid South Africa', in Z. Erasmus (ed.), Coloured by history, shaped by place: New perspectives on in Z. Erasmus (ed.), Coloured by history, shaped by place: New perspectives on
coloured identities in Cape Town, pp. 13-28, Kwela Books and SA History Online, coloured ident
Cape Town.

Foucault, M., 1979, “"Truth and power", interviewed by Alessandro Fontano and Pasquale Pasquino,' transl. P. Patton \& M. Morris, in M. Morris \& P. Patton (eds.), Michel Foucault: Power, truth, strategy, pp. 29-48, Feral, Sydney.

Foucault, M., 1995, Discipline and punish: The birth of the prison, transl. A Sheridan, Vintage, New York.

Foucault, M., [1979] 2003, 'Omnes et Singulatim', in P. Rabinow \& N. Rose (eds.), The essential Foucault. Selections from the essential works of Foucault 1954-1984, pp. 180-201, New Press, New York.

Foucault, M., 2007, Security, territory, population: Lectures at the Collège de France, 1977-78, transl. G. Burchell, ed. M. Senellart, Palgrave Macmillan, New York.

Giliomee, H., 2007, Nog altyd hier gewees: Die storie van 'n Stellenbosse gemeenskap, Tafelberg, Kaapstad.

Graham, E.L., 1993, 'The sexual politics of pastoral care', in E. Graham \& M. Halsey (eds.), Life Cycles. Women and pastoral care, pp. 210-224, Society for Promoting Christian Knowledge, London.
Graham, E.L., 1996, Transforming practice: Pastoral theology in an age of uncertainty, Mowbray, London.

Heyward, C., 1999, Saving Jesus from those who are right: Rethinking what it means to be Christian, Fortress Press, Minneapolis, MN.

Isasi-Diaz, A.M., 1999, 'Mujerista narratives: Creating a new heaven and a new earth', in M.A. Farley \& S. Jones (eds.), Liberating eschatology: Essays in honor of Letty M. Russell, pp. 227-243, Westminster John Knox Press, Louisville, KY.

Isherwood, L. \& McEwan, D., 1994, Introducing feminist theology, Sheffield Academic Press, Sheffield.

Knowles, E. \& Elliott, J. (eds.), 1997, The Oxford dictionary of new words, Oxford University Press, Oxford.

Lincoln, Y. \& Denzin, N.K., 2005, 'Epilogue. The eighth a ninth moments - Qualitative research in/and the fractured future', in N.K. Denzin \& Y.S. Lincoln (eds.), The Sage handbook of qualitative research, 3rd edn., pp. 1115-1126, Sage, Thousand Oaks, CA.

Pattison, S., 1994, Pastoral care and Liberation Theology, Cambridge University Press, Cambridge.

Poling, J.N., 2002, Render unto God: Economic vulnerability, family violence and pastoral theology, Chalice, St. Louis, MO.

Reddy, T., 2001, 'The politics of naming: the constitution of coloured subjects in South Africa', in Z. Erasmus (ed.), Coloured by history, shaped by place: New perspectives on coloured identities in Cape Town, pp. 64-97, Kwela Books and SA History Online, Cape Town.

Rieger, J., 1998, Remember the poor: The challenge to theology in the twenty-first century, Trinity Press International, Harrisburg, PA.

Schüssler Fiorenza, E., 1993, Discipleship of equals: A critical feminist ekklèsia-logy of liberation, Crossroad, New York.

Tronto, J.C., 1995, 'Care as a basis for radical, political judgments', Symposium on care and justice, Hypatia 10(2), 141-149. http://dx.doi.org/10.1111/j.1527-2001.1995. tb01376.x

Weedon, C., 1987, Feminist practice and Poststructuralist theory, Blackwell, Oxford. Welch, S.D., 1990, A feminist ethic of risk, Fortress, Minneapolis, MN.

White, M., 2000, Reflections on Narrative practice: Essays and interviews, Dulwich Centre, Adelaide. 